\title{
Pengaruh Debt to Equity Ratio dan Return on Equity terhadap Harga Saham pada Perusahaan Makanan dan Minuman yang Terdaftar di Bursa Efek Indonesia
}

The effect of debt to equity ratio and return on equity on stock prices of food and beverage sub sectors in Indonesia Stock Exchange

\section{Antis I'niswatin}

Program Studi D3 Keuangan dan Perbankan, Politeknik Negeri Bandung

E-mail: antis.iniswatin98@gmail.com

\section{Radia Purbayati}

Jurusan Akuntansi, Politeknik Negeri Bandung

E-mail: radia.purbayati@polban.ac.id

\section{Setiawan}

Jurusan Akuntansi, Politeknik Negeri Bandung

E-mail: setiawan@polban.ac.id

\begin{abstract}
This research aims to detrmine how much influence the Debt to Equity Ratio (DER) dan Return on Equity (ROE) on Stock Prices at Food and Beverage Sub Sector companies listed on the Indonesia Stock Exchange for the period 2013-2018. The sample used in this research were ten companies obtained based on purposive sampling technique. The data used in this study is panel data so that the data will be tested using the help of the Eviews 9 application and analysed using panel data multiple analysis. The results of this analysis indicate that DER partially has a negative and significant effect on stock prices and ROE partially has a positive and significant effect on stock prices. Meanwbile, simultaneously, DER and ROE have a joint influence on stock price of companies in the Food and Beverage Sub Sector for the 2013-2018 period.
\end{abstract}

Keywords: debt to equity ratio, return on equity and stock price

\section{Pendahuluan}

Pasar modal Indonesia dikelola oleh lembaga Bursa Efek Indonesia (BEI) yang terdiri dari berbagai jenis sectors and sub sectors yang tercatat di BEI dan seiring berjalannya waktu industri yang tercatat di BEI semakin bertambah. Hal tersebut dibuktikan oleh data dari Bursa Efek Indonesia bahwa pada bulan Agustus tahun 2020 sudah mencapai 702 pereusahaan yang tercatat di BEI. Hal ini secara tidak langsung mendorong indutri untuk tetap memiliki kinerja perusahaan yang baik agar mampu mempertahankan eksistensinya di pasar modal Indonesia. Investasi di BEI dapat dialakukan melalui berbagi instrumen keuangan seperti obligasi, reksadana, saham dan intrumen derivatif. Investasi dalam instrumen keuangan saham menjadi salah satu pilihan pemilik modal dalam berinvestasi karena investasi saham memberikan keuntungan berupa deviden dan capital gain (Dewi et al., 2016). Saham di industri minuman dan makanan menjadi salah satu saham yang paling populer dan di minati oleh para pemilik modal karena minuman dan makanan itu sendiri adalah kebutuhan pokok bagi masyarakat, sehingga dari sisi pemasukan lebih menjanjikan (Ayuningtyas, 2019). Berdasarkan data Kementrian Perindustrian Republik Indonesia (Kemenperin RI) mengatakan bahwa industri 
minuman dan makanan pada triwulan III tahun 2017 mampu berkontribusi 34,95\% dari PDB non-migas, hal tersebut mengalami peningkatan sebesar 4\% dibandingkan tahun sebelumnya dan sekaligus menjadi contributor PDB tertinggi dibandingkan sektor lainnya (Kemenperin, 2019). Selain itu di tahun 2018 Kemenperin RI menyatakan bahwa industri Minuman dan Makanan saat ini salah satu sektor manufacture yang ikut andil terhadap pertumbuhan perekonomian negara dan sector ini merupakan salah satu sector yang memberikan pengaruh dalam pertumbuhan angka investasi dalam negeri yang pada tahun 2018 mampu berkontribusi sebesar Rp 56,60 triliun. Dibalik prestasinya pemilik modal harus tetap waspada terhadap harga sahamnya karena berdasarkan tabel dibawah ini terlihat bahwa terjadi ketidakstabilan harga saham pada beberapa perusahaan sub sektor ini keculai ICBP yang mengalami trend yang meningkat. Ketidakstabilan harga saham tersebut akan dihadapi oleh para pemilik modal saham dan menjadi salah satu risiko yang sulit di perkirakan sehingga akan menyebabkan kerugian di waktu yang akan datang.

\begin{tabular}{|c|r|r|r|r|r|r|}
\hline EMITEN & \multicolumn{1}{|c|}{$\mathbf{2 0 1 3}$} & \multicolumn{1}{c|}{$\mathbf{2 0 1 4}$} & \multicolumn{1}{c|}{$\mathbf{2 0 1 5}$} & \multicolumn{1}{c|}{$\mathbf{2 0 1 6}$} & \multicolumn{1}{c|}{$\mathbf{2 0 1 7}$} & \multicolumn{1}{c|}{$\mathbf{2 0 1 8}$} \\
\hline CEKA & 580 & 750 & 675 & 1.350 & 1.290 & 1.375 \\
\hline DLTA & 7.600 & 7.800 & 5.200 & 5.000 & 4.590 & 5.500 \\
\hline ICBP & 5.100 & 6.550 & 6.738 & 8.575 & 8.900 & 10.450 \\
\hline INDF & 6.600 & 6.750 & 5.175 & 7.925 & 7.625 & 7.450 \\
\hline MLBI & 12.000 & 11.950 & 8.200 & 11.750 & 13.675 & 16.000 \\
\hline MYOR & 1.040 & 836 & 1.220 & 1.645 & 2.020 & 2.620 \\
\hline SKBM & 480 & 970 & 945 & 640 & 715 & 695 \\
\hline SKLT & 180 & 300 & 370 & 308 & 1.100 & 1.500 \\
\hline STTP & 1.550 & 2.880 & 3.015 & 3.190 & 4.360 & 3.750 \\
\hline ULTJ & 1.125 & 930 & 986 & 1.143 & 1.295 & 1.350 \\
\hline
\end{tabular}

Tabe1 1. Harga Saham Food and Beverage Sub-sectors Periode 2013-2018

Jumlah demand and supply saham di pasar modal Indonesia akan mempengaruhi ketidakstabilan harga saham, karena hukum demand and supply sepenuhnya berlaku dalam perdagangan saham di bursa (Winarto, 1997, p. 411). Secara umum ananlisis harga saham dapat menggunakan technical and fundamental analysis.

Aspek fundamental yang mempengaruhi harga saham diantaranya yaitu ekonomi makro/mikro, hukum permintaan dan penawaran dan kinerja suatu perusahaan (Eric, 2011, p. 48) yang dapat diukur menggunakan laporan keungan (Horne \& Wachowicz, 2012, p. 163) melalui perhitungan rasio keuangan sebagai tolak ukurnya (Habib, 2008, p. 91). Melalui analisis tersebut akan di peroleh gambaran kinerja suatu perusahaan yang terceriminkan melalui harga sahamnya (Sunariyah, 2011, p. 7). Kinerja perusahaan yang baik pasti memiliki tingkat profitabilitas yang baik, salah satunya dapat diukur menggunakan rasio ROE yaitu rasio yang mampu meangka kinerja perusahaan dalam mengelola modal perusahaan untuk menghasiilkan profit (Kasmir, 2014, p. 280). Jika dilihar dari rasio solvabilitas atau leverage struktur modal perusahaan yang baik akan memperlihatkan komposisi utang yang lebih sedikit dari komposisi modal yang dimilikinya, terdapat dua cara untuk memeriksa utang perusahaan. Pertama, dapat diperiksa melalui neraca untuk menentukan proporsitotal dana yang diwakili oleh utang. Kedua, dapat ditinjau melalaui income statement untuk melihat seberapa jauh bunga ditutupi oleh laba operasional (Brigham \& Houston, 2010, p. 107). Prosedur yang pertama dapat diukur oleh rasio DER yaitu rasio keuangan yang mampu meangka perbandingan utang dengan modal suatu perusahaan (Kasmir, 2014, p. 158).

Berdasarkan uraian diatas, fluktuasi harga saham diakibatkan oleh banyak faktor salah satunya diakibatkan atau dipengaruhi oleh kinerja suatu perusahaan melalui informasi 
rasio keuangannya. Sehingga perlu diteliti lebih lanjut mengenai "Pengaruh DER dan ROE terhadap Harga Saham" untuk melihat apakah DER dan ROE adalah faktor rasio yang mempengaruhi harga saham. Sehingga dapat di gunakan sebagai langkah untuk meminimalisir risiko yang akan dihadapi oleh para pemilik modal dimasa yang akan datang dan dapat dijadikan acuan perusahaan dalam mempertahankan eksistensi perusahaan di pasar modal Indonesia.

Berikut ini merupakan perkembangan rata-rata rasio DER, ROE dan Harga Saham di bursa pada saat closing pada food and beverage sub-sector yang tercatat di BEI periode 2013-2018:

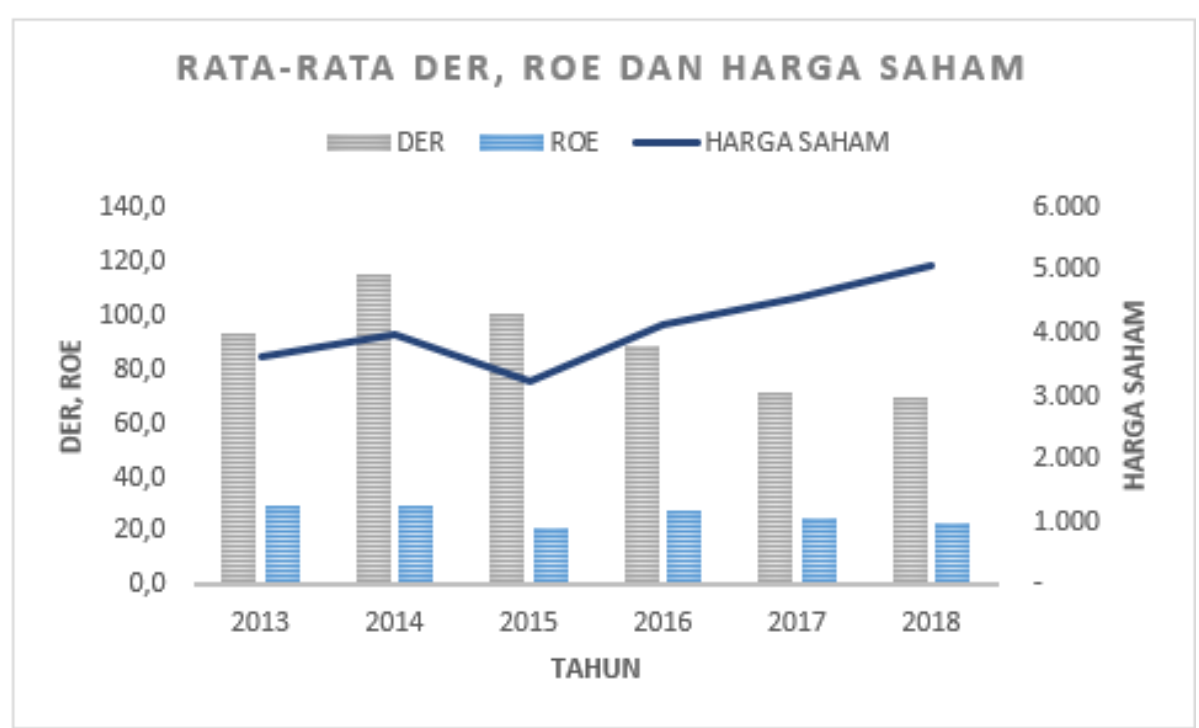

Grafik 1. Perkembangan Rata-rata DER, ROE dan Harga Saham

Berdasarkan grafik diatas rata-rata DER dari tahun 2013-2014 mengalami kenaikann sebesar 22\% tetapi kenaikan tersebut tidak diikuti dengan kemerosotan harga saham. Selain itu rata-rata DER pada tahun 2015-2018 mengalami penurunan tetapi penurunannya tidak diikuti dengan naiknya harga saham. Hal tersebut tidak sesuai dengan theory bahwa semakin tinggi angka DER semakin besar komposisi utang dibandingkan modal yang dimiliki perusahaan. Komposisi utang yang tinggi akan mempengaruhi proporsi risiko yang ditanggung oleh para pemegang saham atau pemilik modal (Brigham \& Houston, 2010, p. 455). Sehingga pada keadaan DER yang tinggi akan mengurangi minat pemegang saham untuk menyimpan modalnya di suatu perusahaan (Ratih et al., 2014) dan akibatnya harga saham di bursa akan menjadi turun karena permintaan bursa yang mengalami penurunan. Karena seorang pemilik modal selain peduli terhadap tingkat ROE juga peduli terhadap tingkat risiko saham perusahaan (Brigham \& Houston, 2010, p. 116). Hal ini diperkuat oleh output penelitian oleh Rheza Dewangga dan Budi Sudaryanto yang menjelaskan bahwa DER memiliki hubungan negatifdan signifikan terhadap harga saham.

Rata-rata ROE di tahun 2017 dan 2018 mengalami penurunan, tetapi tidak diikuti dengan menurunnya harga saham. Kenyataan ini tidak sesuai dengan theory menurut (Brigham \& Houston, 2010, p. 112) pemilik modal menyukai tingkat ROE yang tinggi, dan ROE yang tinggi berkorelasi dengan harga saham yang tinggi. Semakin tinggi tingkat ROE suatu perusahaan dapat diartikan bahwa kinerja suatu perusahaan berhasill mengelola modal yang dimilikinya untuk menghasilkann keuntungan (Bambang, 2000). Keadaan tersebut akan ditangkap sebagai sinyal yang baik oleh pemilik modal sehingga harga saham di bursa akan meningkat.

Penelitian sebelumnya tentang "Pengaruh DER dan ROE terhadap Harga Saham" telah 
banyak dilakukan tetapi dari output penelitiannya memperlihatkan output yang berbeda-beda seperti penelitian oleh Mira Munira dkk (2018) dengan output penelitiannya yaitu secara parsial variabel ROEtidak berpengaruh significant terhadap harga saham tetapi secara simultan kedua variabel berpengaruh terhadap harga saham pulp \& paper. Output tersebut tidak sesuai dengan hasill riset terdahulu yang di lakukan oleh Angantyo Adi dkk yang menyimpulkan bahwa variabel ROE secara parsial memiliki pengaruh signifikan terhadap harga saham sedangkan variabel DER tidak memiliki pengaruh significant terhadap harga saham. Secara simultan kedua variabel mempunyai pengaruh yang signifikan terhadapharga saham.

Bersumber pada latar belakang dan gap research tersebut membuat peneliti tertarik untuk meneliti kembali riset yang telah ada untuk membuktikan teori dan keraguan terhadap hasilpenelitian terdahulu dan menyusunnya dalam laporan Tugas Akhir dengan judul "Pengaruh Debt to Equity Ratio (DER) dan Return on Equity (ROE) terhadap Harga Saham pada Perusahaan Makanan dan Minuman yang Terdaftar di Bursa Efek Indonesia Periode 2013-2018".

\section{Kajian Pustaka}

\subsection{Harga Saham}

Harga Saham yaitu harga yang terbentuk di bursa berdasarkan demand and supply para pelaku bursa (Hartono, 2008). Harga saham adalah gambaran dari keputusan pendanaan, investasi dan pengelolaan aset yang diambil oleh seorang pemilik modal (Agus Harjito, 2007, p. 13). Berdasarkan pendapat para ahli, dapat disimpulkanbahwa harga saham adalah harga yang terjadi di bursa berdasarkan demand and supply yang terjadi di bursa yang dilakukan oleh berbagai pemilik modal atas keputusan investasi, pendanaan dan pengelolaan aset yang pemilik modal ambil.

Jenis-jenis harga saham menurut (Widioatmodjo, 2013, p. 54) harga saham terdiri dari berbagai jenis yaitu harga perdana, harga nominal, harga tertinggi, harga terendah, harga pasar, harga pembukaan, harga penutupan, harga rata-rata. Metode yang digunakan dalam menganalisis fluktuasi harga saham yaitu technical analysis and fundamental analysis (Tryfino, 2009, p. 7). Analisis Fundamental merupakan salah satu metode analisis harga saham berlandaskan kinerja keuangan suatu perusahaan untuk memastikaan bahwa saham yang pemilik modal beli adalah saham perusahaan yang menyandang kinerja perusahaan yang baik.

\subsection{Return on Equity (ROE)}

Rasio ROE adalah bagian dari rasio profitabilitas yang dapat meangka keefektifan perusahaan dalam penggunaan ekuitas yang dimilikinya untuk menghasilkanlaba bersih (Kasmir, 2014). Semakin besar rasio ini artinya posisi perusahaan dalam keadaan yang baik. Berikut rumus yang digunakan untuk menghitung rasio ROE:

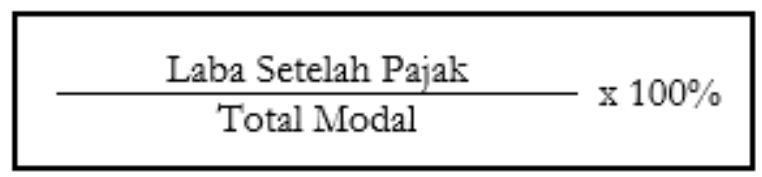

Rumus 1. Retum on Equity (ROE)

\subsection{Debt to Equity Ratio (DER)}

DER yaitu rasio keuangan yang menghiutng persamaan utang dengan ekuitas yang dimiliki perusahaan (Kasmir, 2014, p. 158). DER dapat dilihat dalam bentuk persentase, semakin tinggi persentase DER maka semakin rendah modal yang dimilikinya dibandingkan utang yang dimiliki perusahaan tersebut, dari sudut pandang kemampuanperusahaan memenuhi kewajiban jangka panjang, semakin kecil persentase DER maka semakin bagus kesanggupan 
perusahaan dalam merampungkan kewajiban jangka panjangnya dan begitupun sebaliknya seamakin tinggi persentase DER dapat diartikan bahwa komposisi utang yang dimiliki perusahaan lebih tinggi dari komposisi total modal yang dimilikinya yang menunjukkan bahwa sumber modalnya tergantung pada pihak luar. Berikut ini rumus untuk menghitung rasio DER:

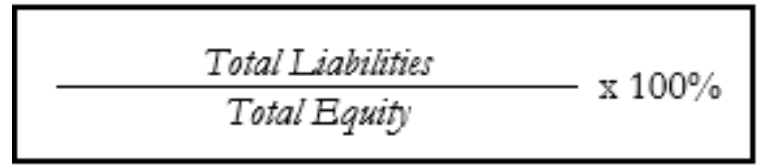

Rumus 2. Debt to Equity Ratio (DER)

\subsection{Kerangka Berfikir Teoritis dan Perumusan Hipotesis}

\section{Hubungan DER dengan Harga Saham}

DER yaitu rasio dari persamaan antara jumlah kewajiban dengan jumlah modal, melalui perhitungan rasio ini akan diketahui bahwa seberapa besar komposisi hutang dibandingkan dengan modal yang dimiliki perusahaan. Apabila komposisi utang lebih besar dibandingkan modal perusahaan, maka akan berakibat pada penurunan angka perusahaan tersebut (Sudana, 2011) dan dapat menghasillkan DER yang besar. Semakin besarrasio DER maka semakin besar resiko yang di tanggung oleh perusahaan dan dapat menyebabkan kebangkrutan finansial dimasa masa-masa yang sulit (Menon \& Vidhyasagara, 2015). Angka DER yang tinggi akan mengghasilkan persepsi negatif dari pemilik modal yang diikuti dengan menurunnya demand saham di bursa dan menurunnya harga saham di bursa (Menon \& Vidhyasagara, 2015). Tori tersebut sesuai dengan output penelitian dari Rheza Dewangga Nugraha dan Budi Sudaryanto (2016), Fendi Hudaya Ramadhani (2017) dan Okinawa Syahfitri dkk (2017) yang menyimpulkan bahwa DER berpengaruh negatiff dan signifikan terhadap harga saham. Bersumber pada uraian daiatas diperoleh rumusanhipotesis penelitian sebagai berikut:

$\mathrm{H}_{1} \quad$ : DER diduga ber pengaruh negatif dan signifikanterhadap Harga Saham

\section{Hubungan ROE dengan Harga Saham}

ROE yaitu rasio dari persamaan antara net income dengan total equity. Semakin tinggi rasio ROE akan ditangkap sebagai sinyal yang baik karena perusahaan mampu mengelola modal yang dimiliki secara efisien sehingga menghasilkan laba atau keuntungan yang tinggi. Semakin tinggi rasio ROE akan menarik minat dan kepercayaan pemilik modal sehingga akan meningkatkan harga saham yang disebabkan oleh meningkatnya demand pemilik modal terhadap saham karena pemilik modal tertarik terhadap tingakat ROE yang tinggi dan ROE yang tinggi berkorelasi dengan harga saham yang tinggi(Brigham \& Houston, 2010, p. 112). Teori ini sesuai dengan hasil riset yang dilakukan oleh Rheza Dewangga Nugraha dan Budi Sudaryanto (2016), Fendi Hudaya Ramadhani (2017), Sasi Sabrina dkk (2018) yang menyimpulkan bahwa ROE berpengaruh positif dan signifikan terhadap harga saham. Berdasarkan uraian tersebut diperoleh rumusan hipotesispenelitian sebagai berikut:

$\mathrm{H}_{2} \quad$ : ROE diduga berpengaruh positif dan signifikan terhadap Harga Saham

\section{Hubungan DER dan ROE dengan Harga Saham}

Seorang pemilik modal selain peduli terhadap tingkat ROE juga peduli terhadap tingkat risiko (Brigham \& Houston, 2010, p. 116) yang disebabkan oleh DER yang tinggi. Teori ini didukung oleh output penelitian Nurmala Alifah (2018), Mira Munira (2018) dan Fendi Hudaya Ramadhani (2017) yang menyimpulkanbahwa DER dan ROE secara simultan berpengaru significant terhadap hargasaham. Berdasarkan uraian tersebut diperoleh rumusan 
hipotesispenelitian sebagai berikut:

$\mathrm{H}_{3} \quad$ : DER dan ROE diduga mempunyai pengaruh secara simultan terhadap harga saham

Berdasarkan uraian diatas, variabel yang di gunakan dalam penelitian ini yaitu DER dan ROE sebagai variabel independent dan harga saham sebagai variabeldependent. Sehingga terbentuklah kerangka pemikiran sebagai berikut:

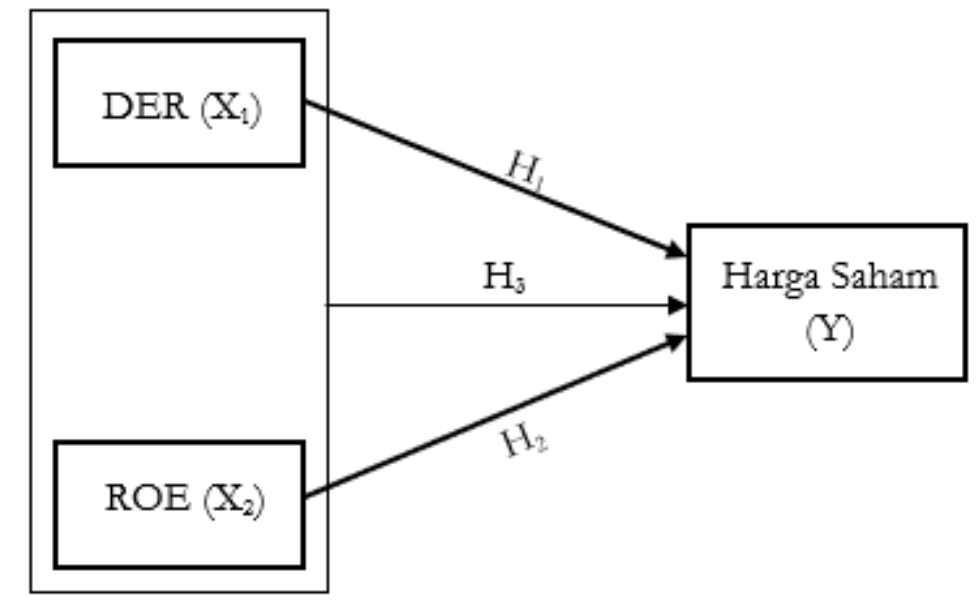

Gambar 1. Kerangka Pemikiran

\section{Metode Penelitian}

Penelitian ini menggunakan metode penelitian berjenis kuantiatif yaitu metode yang menggunakan filsavat positivisme sebagai dasar dalam meneliti pada suatu population and sample melalui pencarian data menggunakan instrumen penelitian dan untuk menguji hipotesis menggunakan analisis data yang bersifat statistics (Sugiyono, 2017, p. 8). Penelitian ini bersifat asosiatif yaitu penelitian yang digunakan untuk melihat pengaruh diantara dua variable atau lebih (Sugiyono, 2017, p. 57).

\subsection{Teknik Analisis Data}

\section{Penentuan Model Regresi Data Panel}

Demi mendapatkan teknik estimasi data panel yang akurat, perlu dilakukan tiga uji (Widioatmodjo, 2013) yaitu sebagai berikut:

\section{Uji Chow}

Uji chow yaitu uji yang dilakukan untuk menetapkan model yang paling akurat antara CEM dan FEM untuk mengestimasi data panel.

$\mathrm{H}_{0}$ : CEM lebih akurat

$\mathrm{H}_{1}$ : FEM lebih akurat

Pengambilan keputusan uji chow dilakukan berdasarkan: (a) Apabila probabilitas atau angka probabilitas $\mathrm{F}<0,05$ maka $\mathrm{H}_{0}$ ditolak dan $\mathrm{H}_{1}$ diterima, maka modal yang paling akurat untuk mengestimasi data panel yaitu FEM. (b) Apabila angka probabilitas F> 0,05 maka $\mathrm{H}_{0}$ diterima dan $\mathrm{H}_{1}$ ditolak dan model paling akurat untuk mengestimasi data panel yaitu CEM.

2. Uji Hausman

Uji Hausman yaitu uji yang dilakukan untuk menetapkan model yang paling akurat antara FEM dan REM untuk mengestimasi data panel.

$\mathrm{H}_{0}$ : REM lebih akurat

$\mathrm{H}_{1}$ : FEM lebih akurat 
Pengambilan keputusan uji hausman dilakukan berdasarkan: a) Apabila angka statistik Hausman>angka kritis chi-square dan probabilitas cross-section random $<0,05$ maka $\mathrm{H}_{0}$ diitolak dan $\mathrm{H}_{1}$ diterima, maka model yang paling akurat untuk mengestimasi data panel yaitu FEM. b) Apabila angka statistik Hausman<angka kritis chi-square dan probabilitas crosssection random $>0,05$ maka $\mathrm{H}_{0}$ diterima dan $\mathrm{H}_{1}$ ditolak dan model yang paling akurat untuk mengestimasi data panel yaitu REM.

\section{Uji Lagrange Multiplier (LM)}

Uji LM yaitu uji penentu yang dilakukan utnuk menetapkan model yang paling akurat antara REM dan CEM untul mengestimasi data panel.

$\mathrm{H}_{0}$ : CEM lebih akurat

$\mathrm{H}_{1}$ : REM lebih akurat

Pengambilan keputusan Uji LM dilihat dengan metode Breusch Pagan dengan melihat tingkat probabilitasnya: (a) Apabila angka probabilitas $<0,05$ maka $\mathrm{H}_{0}$ ditolak dan $\mathrm{H}_{1}$ diterima dan model yang paling akurat untuk mengestimasi data panel yaitu REM (b) Apabila angka probabilitas $>0,05$ maka $\mathrm{H}_{0}$ diterima dan $\mathrm{H}_{1}$ ditolak dan model yang paling akurat untuk mengestimasi data panel yaitu CEM.

\section{Analisis Regresi Data Panel}

Analisis regresi data panel yaitu metode yang memadukan jenis data time series dan crosssection yang diamati sepanjang waktu tertentu dengan jumalh unit waktu yang serupa untuk setiap perseorangan sehingga data tersebut disebut balanced panel. Berikut ini bentuk umum regresi data panel:

$$
Y_{i t}=a+\beta_{1} X_{1 i t}+\beta 2 X_{2 i t}+e_{i t}
$$

Rumus 3. Rumus Model Analisis Regresi Data Panel

Keterangan :

$$
\begin{array}{ll}
\mathrm{Y}_{\mathrm{it}} & =\text { Variable terikat harga saham (Rp) } \\
\mathrm{X}_{\mathrm{it}} & =\text { Variable Bebas Debt to Equity Ratio }(\%) \\
\mathrm{X}_{2 \mathrm{it}} & =\text { Variable Bebas Retum On Equity }(\%) \\
\mathrm{i} & =\text { Entitas ke-i } \\
\mathrm{t} & =\text { Periode ke-t } \\
\alpha & =\text { Konstanta } \\
\beta & =\text { Koefisien regresi } \\
e & =\text { Variabel di luar model }
\end{array}
$$

\section{Uji Hipotesis}

Uji Hipotesis menggunakan dua cara yaitu uji statistik F danuji statistik t.

a. Uji Parsial (Uji t)

Uji Parsial merupakan uji yang dilakukan untuk melihat pengaruh variabel independent secara parsial terhadap variabel dependent. Berikut langkah-langkah uji parsial:

\section{Merumuskan Hipotesis}

$\mathrm{HO}_{1}$ : Menurut uji parsial tidak terdapat pengaruh negatif yang signifikan antara DER terhadap harga saham.

$\mathrm{Ha}_{1}$ : Menurut uji parsial terdapat pengaruh negatif yang signifikan antara 
DER terhadap harga saham.

$\mathrm{HO}_{2}$ : Menurut uji parsial tidak terdapat pengaruh positif yang signifikan antara ROE terhadap harga saham.

$\mathrm{Ha}_{2}$ : Menurut uji parsial terdapat pengaruh positif yang signifikan antara ROE terhadap harga saham.

\section{Pengambilan Keputusan}

Berikut pengambilan keputusan dengan tingkat signifikan 5\% menurut Gujarati (dalam Sakti, 2018, p. 10) yaitu sebagai berikut:

a. Uji satu arah sisi kanan (positif)

1. Apabila $\mathrm{t}$ hitung $>\mathrm{t}$ tabel, maka $\mathrm{H}_{0}$ ditolak atau variabel $\mathrm{ROE}$ berpengaruh positif terhadap harga saham.

2. Apabila $\mathrm{t}$ hitung $<\mathrm{t}$ tabel, maka $\mathrm{H}_{0}$ diterima, variabel $\mathrm{ROE}$ tidak berpengaruh positif terhadap harga saham.

b. Uji satu arah sisi kiri (negatif)

1. Apabila $t$ hitung<-t tabel, maka $\mathrm{H}_{0}$ ditolak, variabel $\mathrm{DER}$ berpengaruh negatif terhadap harga saham.

2. Apabila $t$ hitung $>$ - $t$ tabel, maka $\mathrm{H}_{0}$ diterima, variabel $\mathrm{DER}$ tidak berpengaruh negatif terhadap harga saham.

Selain itu apabila tingkat probabilitas $>0,05$ maka $\mathrm{H}_{0}$ diterima, artinya variabel independent secara parsial tidak berpengaruh signifikan terhadap variabel dependent, dan sebaliknya jika probabilitas $<0,05$ maka variabel independent berpengaruh signifikan terhadap variabel dependent.

\section{b. Uji Simultan (Uji F)}

Uji Simultan merupakan uji yang dilakukan untuk melihat pengaruh variabelvariabel independent secara bersama-sama (simultan) terhadap variabel dependent. Berikut langkah langkah uji simultan:

1. Merumuskan hipotesis

$\mathrm{H}_{0}$ : $\quad$ Menurut uji simultan tidak terdapat pengaruh yang signifikan antara DER dan ROE terhadap harga saham

$\mathrm{H}_{1}$ : Menurut uji simultan terdapat pengaruh yang signifikan antara DER dan ROE terhadap harga saham

\section{Pengambilan keputusan}

Berikut pengambilan keputusan dengan tingkat signifikan 5\% menurut Gujarati (dalam Sakti, 2018, p. 10) yaitu sebagai berikut (a) Apabila probabilitas F-statistic $>0,05$ maka $\mathrm{H}_{1}$ ditolak, artinya variabel DER dan $\mathrm{ROE}$ tidak memiliki pengaruh secara simultan terhadap Harga Saham (b) Apabila

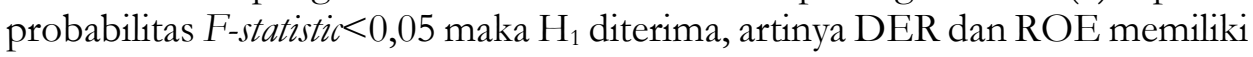
pengaruh secara simultan terhadap Harga Saham.

\section{Koefisien Determinasi $\left(\mathbf{R}^{2}\right)$}

Tujuan dari uji iniyaitu untuk memperkirakan seberapa besar kekuatan variabel independent dalam mendeskripsikan variabel dependent. Angka $R$-square berada di antara nol sampai dengan satu. Apabila angka R-square mendekati angka nol diartikan bahwa kemampuan variabel independent dalam mendeskripsikan variabel dependent kurang kuat dan sebaliknya apabila angka $R$-square mendekati angka 1 dapat diartikan bahwa kemampuan variabel independent dalam mendeskripsikan variabel dependent sangat kuat dan pengaruhnya terhadap variabel dependent semakin besar (Ghazali \& Ratmono, 2016). 


\section{Hasil dan Pembahasan}

\subsection{Pemilihan Model Data Panel}

Demi mendapatkan model yang paling akurat dalam mengestimasikan regresi data panel pada penelitian ini di lakukann tiga uji yaitu sebagai berikut:

\section{Uji Chow}

Uji Chow menguji model estimasi antara model CEM dan FEM, berikut output dari Uji Chow:

\begin{tabular}{|c|c|c|c|}
\hline Effects Test & Statistic & d.f. & Prob. \\
\hline Cross-section F & 33.372900 & $(9,48)$ & 0.0000 \\
\hline Cross-section Chi-square & 118.921454 & 9 & 0.0000 \\
\hline
\end{tabular}

Tabe1 2. Hasil Uji Chow

Berdasarkan output uji chow diatas didapatkan probabilitass cross-section F sebesar 0,0000. Angka probabilitas cross-section $\mathrm{F}$ tersebut $<0,05$ maka $\mathrm{H}_{0}$ ditolak dan $\mathrm{H}_{1}$ diterima, maka model yang akurat digunakan dalam mengestimasi data panel menurut uji chow yaitu FEM.

\section{Uji Hausman}

Uji hausman menguji antara FEM dan REM, berikut ini output dari uji Hausman:

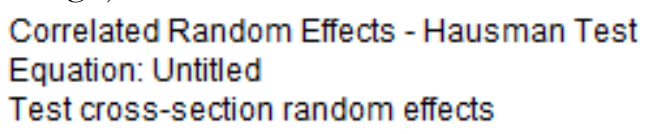

\begin{tabular}{lrrr}
\hline \hline Test Summary & Chi-Sq. Statistic & Chi-Sq. d.f. & Prob. \\
\hline \hline Cross-section random & 2.015211 & 2 & 0.3651 \\
\hline \hline
\end{tabular}

\section{Tabe1 3. Hasil Uji Hausman}

Berdasarkan output uji Hausman diatas didapatkan angka statistik Hausman sebesar 2,015211 dan berdasarkan tabel kritis chi-square dengan tingkat df 2 didapatkan angka sebesar 5,99148. Angka statistik hausman lebih kecil dari angka kritis chi-square dan angkaprobabilitas cross-section random $>0,05$. Hal tersebut dapat diartikann bahwa $\mathrm{H}_{0}$ diterima dan $\mathrm{H}_{1}$ ditolak. Sehingga disimpulkan menurut uji Hausman REM merupakan model yang akurat digunakan dalam mengestimasi data panel dibandingkan FEM. Selanjutnya akan dilakukan Uji LM sebagai uji penentu.

\section{Uji Lagrange Multiplier (Uji LM)}

Uji LM menguji antara model REM dan CEM, berikut ini output dari uji LM: 
Lagrange Multiplier Tests for Random Effects

Null hypotheses: No effects

Alternative hypotheses: Two-sided (Breusch-Pagan) and one-sided (all others) alternatives

\begin{tabular}{lccc}
\hline \hline & \multicolumn{3}{c}{ Test Hypothesis } \\
& Cross-section & Time & Both \\
\hline \hline Breusch-Pagan & 97.06599 & 1.300616 & 98.36661 \\
& $(0.0000)$ & $(0.2541)$ & $(0.0000)$
\end{tabular}

Tabe1 4. Hasil Uji LM

Berdasarkan output uji LM diatas didapatkan probabilitass cross-section Breusch-Pagan0,0000. Angka probabilitasnya $<0,05$ maka $\mathrm{H}_{0}$ tidak diterima dan $\mathrm{H}_{1}$ diterima. Maka disimpulkan bahwa REM merupakan model yang paling akurat digunakan dalam mengestimasi data panel pada penelitian ini dibandingkan CEM.

\subsection{Analisis Regresi Data Panel}

Analisis regresi data panel di gunakan utnuk melihat hubungan antara variabel DER dan ROE terhadap harga saham Food and Beverage Sub-sectors terdaftar di BEI periode 2013-2018. Berikut output olah data menggunakan EViews 9:

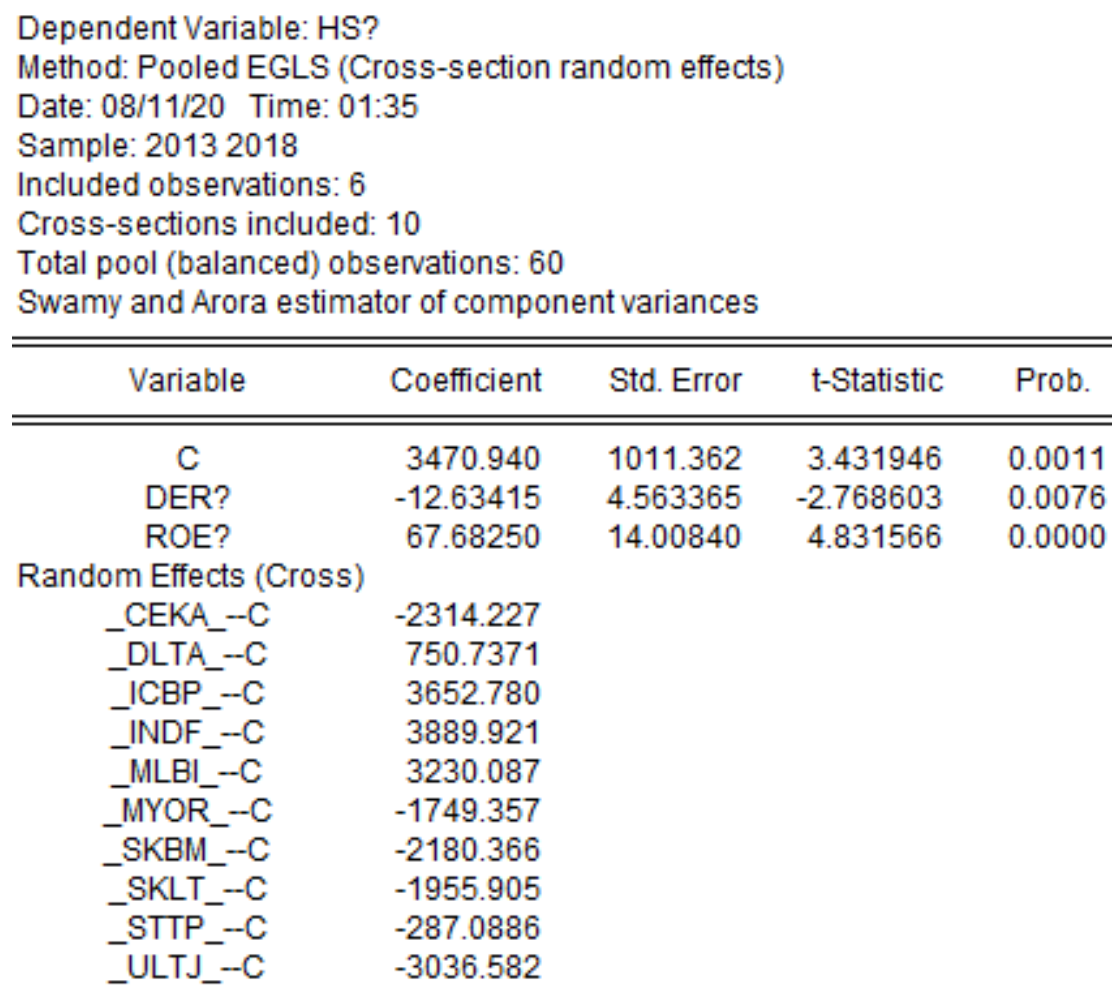

Tabe1 5. Regresi Data Panel Model REM

Bersumber pada output diatas diperoleh model persamaan regresi data panel sebagai berikut:

\section{Harga Saham $=3470,940-12,63415 \mathrm{DER}+67,68250 \mathrm{ROE}$}

Persamaan regresi diatas dapat diinterprestasikan sebagai berikut:

1. Konstanta $(\alpha)=3470,940$ menunjukkan harga konstan, artinya jikaavariabel DER dan $\mathrm{ROE}=0$ maka nilai dari Harga Sahamnya $=3470,940$. 
2. Koefisien $X_{1}\left(\beta_{1}\right)=-12,63415$ menunjukka bahwa DERberpengaruh negatif terhadap harga saham. Sehingga jika DER mengalami peningkatan satu persen maka nilai dari Harga Saham akan menurun senilai 12,63415.

3. Koefisien $X_{2}\left(\beta_{2}\right)=67,68250$ menunjukka bahwa ROE berpengaruh positif terhadap Harga Saham. Sehingga jika ROE mengalami peningkatan satu persen maka nilai dari Harga Saham akan ikut meningkat senilai 67,68250.

Perusahaan Food and beverage sub-sector yang terdaftar di BEI memiliki intersep berbeda-beda yaitu sebagai berikut:

1. CEKA, Harga Saham

2. DLTA, Harga Saham

3. ICBP, Harga Saham

$=-2314,227-12,63415 \mathrm{DER}+67,68250 \mathrm{ROE}$

$=750,7371-12,63415 \mathrm{DER}+67,68250 \mathrm{ROE}$

4. INDF Harga Saham

$=3652,780-12,63415 \mathrm{DER}+67,68250 \mathrm{ROE}$

5. MLBI, Harga Saham

$=3889,921-12,63415 \mathrm{DER}+67,68250 \mathrm{ROE}$

6. MYOR, Harga Saham

$=3230,087-12,63415 \mathrm{DER}+67,68250 \mathrm{ROE}$

7. SKBM, Harga Saham

$=-1749,357-12,63415 \mathrm{DER}+67,68250 \mathrm{ROE}$

8. SKLT, Harga Saham

$=-2180,366-12,63415 \mathrm{DER}+67,68250 \mathrm{ROE}$

$=-1955,905-12,63415 \mathrm{DER}+67,68250 \mathrm{ROE}$

9. STTP, Harga Saham

$=-287,0886-12,63415 \mathrm{DER}+67,68250 \mathrm{ROE}$

10. ULTJ, Harga Saham

$=-3036,582-12,63415 \mathrm{DER}+67,68250 \mathrm{ROE}$

Perbedaan konstanta atau intersep pada masing-masing perusahaan itu disebabkan oleh perbedaan waktu dan budaya dari masing-masing perusahaan, seperti berbedanya waktu tercatatnya perusahaan di BEI, sehingga perusahaannyang lebih dulu tercatat akan memiliki kegiatan operasional yang lebih baik jika dibandingkan dengan perusahaan yang tercatat setelahnya

\subsection{Hasil Pengujian Hipotesis}

a. Hasil Uji Parsial (Uji t)

Berikut output dari uji hipotesis secara parsial:

\begin{tabular}{crrrr}
\hline \hline Variable & Coefficient & Std. Error & t-Statistic & Prob. \\
\hline \hline C & 3470.940 & 1011.362 & 3.431946 & 0.0011 \\
DER? & -12.63415 & 4.563365 & -2.768603 & 0.0076 \\
ROE? & 67.68250 & 14.00840 & 4.831566 & 0.0000
\end{tabular}

Tabel 6. Hasil Uji Parsial (Uji t)

Berikut ini kesimpulan dari output uji hipotesis secara parsial:

1. Berdasarkan output didapatkan $\mathrm{t}$ hitung DER sebesar -2.768603 , tingkat $\mathrm{df}=57$ (60-3) dengan taraf siginifikan 0,05 didapatkan t tabel sebesar 1.67203 maka $2.768603<-1.67203$ ( $\mathrm{t}$ hitung $<-\mathrm{t}$ tabel) dan tingkat probabilitasnya sebesar $0,0076<0,05$ artinya $\mathrm{H}_{0}$ ditolak. Menurut uji t terdapat pengaruh negatif yang signifikan antara DER terhadap harga saham.

2. Berdasarkan output didapatkan angka t hitung ROE sebesar 4.831566, tingkat df $=57$ (60-3) dengan taraf siginifikan 0,05 didapatkan t tabel sebesar 1.67203 maka $4.831566>1.67203$ ( $\mathrm{t}$ hitung $>\mathrm{t}$ tabel) dan tingkat probabilitasnya sebesar 0,0000 $<0,05$ artinya $\mathrm{H}_{0}$ ditolak. Menurut uji t terdapat pengaruhh positif yang signifikan antara ROE terhadap harga saham.

b. Hasil Uji Simultan (Uji F)

Berikut ini output dari uji hipotesis secara simultan: 


\begin{tabular}{lrlr}
\hline \hline \multicolumn{4}{l}{ Weighted Statistics } \\
\hline \hline R-squared & 0.310797 & Mean dependent var & 637.2166 \\
Adjusted R-squared & 0.286615 & S.D. dependent var & 1273.978 \\
S.E. of regression & 1076.029 & Sum squared resid & 65996773 \\
F-statistic & 12.85214 & Durbin-Watson stat & 0.858898 \\
Prob(F-statistic) & 0.000025 & & \\
\hline \hline
\end{tabular}

Tabe1 7. Hasil Uji Simultan (Uji F)

Berdasarkan output dari analisis diatas didapatkan Probabilitas F-statistic sebesar $0,000025<0,05$ maka $\mathrm{H}_{0}$ ditolak dan $\mathrm{H}_{1}$ diterima. Kesimpulannya secara simultan variabel DER dan ROE berpengaruh signifikan terhadap Harga Saham.

\subsection{Hasil Uji Koefisien Determinasi}

Berikut ini output dari uji koefisien determinasi:

\begin{tabular}{lrlr}
\hline \hline \multicolumn{4}{l}{ Weighted Statistics } \\
\hline \hline R-squared & 0.310797 & Mean dependent var & 637.2166 \\
Adjusted R-squared & 0.286615 & S.D. dependent var & 1273.978 \\
S.E. of regression & 1076.029 & Sum squared resid & 65996773 \\
F-statistic & 12.85214 & Durbin-Watson stat & 0.858898 \\
Prob(F-statistic) & 0.000025 & & \\
\hline \hline
\end{tabular}

Tabe1 8. Hasil Uji Koefisien Determinasi

Berdasarkan tabel dapar diketahui bahwa tingkat R-squared dalam penelitian ini sebesar 0,310797 artinya kemampuan variabel DER dan ROE dalam mempengaruhi harga saham sebesar $31,07 \%$ sedangkan sisanya sebesar $68,93 \%$ dipengaruhi oleh variabel diluar variabel yang digunakan dalam penelitian ini.

\subsection{Pengaruh DER terhadap Harga Saham}

Bersumber pada output uji statistik diatas, variabel DER memiliki angka koefisien yang negatif dan memiliki probabilitas $<0,05$ maka dapat disimpulkanbahwa variabel DER memiliki pengaruh negatiff dan signifikan terhadap Harga Saham pada perusahaan food and beverage subsector periode 2013-2018. Pengaruh negatif ini memperlihatkan adanya hubungan yang tidak berbanding lurus antar DER dengan harga saham.

Output analisiss ini membuktikan bahwa seorang pemilik modal sangat menjauhi perusahaan yang mempunyai tingkat utang yang tinggi, karena hutang yang tinggi mencerminkan bahwa perusahaan tersebut dalam menjalankan kegiatan operasionalnya lebih besar menggunakan hutang dibandingkan modal yang dimilikinya. Hal tersebut dapat menimbulkan resiko yang cukup tinggi di waktu yang akan datang, sehingga akan menurunkan kepercayaan pemilik modal untuk menanamkan uangnya di perusahaan tersebut. Selain itu tingkat hutang yang tinggi akan mempengaruhi jumlah deviden yang diterima, karena pada saat perusahaann memperoleh keuntungan, perusahaan cenderung akan menggunakan keuntungan tersebut untuk membayar bunga utangnya terlebih dahulu. Hal tersebut akan berpengaruh dalam menurunkan tingkat deviden yang akan dibagikan perusahaan kepada para pemilik modal. Keadaan tersebut sangat dihindari oleh para pemilik modal, sehingga pada saat DER suatu perusahaan mengalami peningkatan maka permintaan di bursa terhadap saham perusahaan tersebut akan turun dan akibatnya harga saham perusahaan tersebut menjadiikut turun karena kurangnya kepercayaan dan minat pemilik modal untuk menyimpan modalnya di perusahaan. Hal ini sesuai dengan hasil riset yang dilakukan oleh (Menon \& Vidhyasagara, 2015) yang menyimpulkan bahwa menambahkan hutang pada modal secara keseluruhan 
berdampak terbalik pada harga saham dan outputnya juga menunjukkan persepsi negatif pemilik modal terhadap peningkatan hutang dan oleh karena itu harga pasar saham akan menurun dengan dibarengi oleh meningkatnya hutang.

Hasil pada penelitian ini sesuai dengan output penelitian Fendi Hudaya Ramadhani (2017) dan Mira Munira dkk (2018) yang menyimpulkan bahwa variabel DER mempunyai pengaruh negatif dan signifikan terhadap Harga Saham. Berbanding terbalik dengan output penelitian dari Angantyo Adi, Darminto dan Dwi Atmanto yang menyimpulkan bahwa rasio DER secara signifikan tidak memiliki pengaruh terhadap harga saham.

\subsection{Pengaruh ROE terhadap Harga Saham}

Bersumber pada output uji statistik diatas, variabel ROE memiliki angka koefisien yang positif dan memiliki probabilitas $<0,05$ maka disimpulkan variabel ROE berpengaruh positif dan signifikan terhadap Harga Saham perusahaan food and beverage sub-sector periode 2013-2018. Pengaruh positif ini memperlihatkan adanya hubungan yang berbanding lurus antara variabel ROE terhadap Harga Saham.

Output dari analisis ini menerangkan bahwa semakin besar angka ROE suatu perusahaan semakin menarik pemilik modal untuk menginvestasikan dananya pada perusahaan tersebut, karena semakin besar angka ROE perusahaan artinya perusahaan semakin efisien dalam mengatur penggunaan modal yang dimilikinya untuk mendatangkan keuntungan. Sehingga apabila suatu perusahaan menghasilkan laba yang tinggi maka deviden yang dibagikan akan meningkat. Keadaan seperti ini akan menarik kepercayaan dan minat pemilik modal, sehingga permintaan suatu saham perusahaan di bursa akan bertambah dan harga saham perusahaan tersebut menjadi meningkat, dan begitupula sebaliknya. Hal ini sesuai dengan teori Pemilik modal menyukai ROE yang tinggi, dan ROE yang tinggi berhubungan dengan harga saham yang tinggi (Brigham \& Houston, 2010, p. 112).

Output penelitian ini sesuai dengan penelitianFendi Hudaya Ramadhani (2017) dan Lia Fatimah (2018) yang menyimpulkan bahwa variabel ROE memiliki pengaruh positif dan signifikan terhadap Harga Saham. Berbanding terbalik dengan output penelitian Mira Munira dkk (2018) yang menyimpulkan bahwa secara parsial variable ROE tidak berpengaruh signifikan terhadap harga saham.

\subsection{Pengaruh DER dan ROE Secara Simultan Terhadap Harga Saham}

Berdasarkan output uji statistik diatas, angka probabilitas F-statistik sebesar0,000025<0,05 maka disimpulkan bahwa variabel DER dan ROE secara simultann mempunyai pengaruh signifikan terhadap Harga Saham. Output uji menjelaskan bahwa variabel DER dan ROE mempengaruhi harga saham sebesar $31,07 \%$ dan sisanya $68,93 \%$ di pengaruhi oleh variabel di luar variaberl yang di gunakan dalam penelitian ini.

Output penelitian ini membuktikan bahwa pemilik modal tertarik padaperusahaan yang memiliki tingkat uutang yang rendah dan profitabilitas yang tinggi. Sehingga pada saat suatu perusahaan memiliki tingkat DER yang rendah dan ROE yang tinggi, maka harga saham suatu perusahaan akan meningkat yang disebabkan oleh tingginya minat pemilik modal terhadap perusahaan tersebut. Hal ini dapat disimpulkan bahwa rasio DER dan ROE merupakan rasio yang sangat diperhatikan oleh para pemilik modal sesuai dengan teori yang dikatakan oleh (Brigham \& Houston, 2010, p. 116) seorang pemilik modal selain peduli terhadap tingkat ROE juga peduli terhadap tingkat resiko. Sehingga seorang pemilik modal akan berhati-hati dalam mengambil keputusan investasinya, karena kedua rasio tersebut mampu mempengaruhi fluktuasi harga saham suatu perusahaan secara signifikan.

Output penelitian ini sesuai dengan penelitianMira Munira dkk (2018) dan Nurmala Alifah dkk (2017) yang menjelaskan bahwa secara bersama-sama variabel DERdan ROE mempunyaii 
pengaruh signifikan terhadap harga saham.

\section{Penutup}

\section{Kesimpulan}

Bersumber pada penjabaran data pada penelitian ini yang berlandaskan pada kajian teori dan perumusan masalah dapat disimpulkan bahwa:

a. DER secara parsial mempunyai pengaruh negatif dan signifikan terhadap harga saham Food and Beverage Sub-sectors yang tercatat di BEI periode 2013-2018.

b. ROE secara parsial mempunyai pengaruh positif dan signifikan terhadap harga saham Food and Beverage Sub-sectors yang tercatat di BEI periode 2013-2018.

c. DER dan ROE secara simultan mempunyai pengaruh terhadap harga saham Food and Beverage Sub-sectors yang tercatat di BEI periode 2013-2018. Pengaruh DER dan ROE sebesar $31,07 \%$ sedangkan selisihnya sebesar $68,93 \%$ di pengaruhi oleh variabel diluar variabel yang digunakan pada penenelitian ini.

\section{Saran}

Penelitian yang dilakukan oleh penulis masih jauh dari kata sempurana karena terbatas oleh variabel bebas yang digunakan yaitu variabel DER dan ROE serta periode penelitian selama enam tahun yaitu periode 2013-2018. Berdasarkan keterbatasan tersebut, maka penulis menyarankan untuk peneliti selanjutnya di harapkan bisa menambahkan variabel lainnya yang berpengaruh terhadap harga saham diluar variabel yang digunakan pada penelitian ini, dan diharapkan dapat menambah jangka waktu periode penelitian pada sektor atau sub sektor lainnya yang terdaftardi Bursa Efek Indonesia(BEI).

\section{Daftar Pustaka}

Agus Harjito, M. (2007). Manajemen Keuangan, edisi1. Yogyakarta: Ekonisia.

Ayuningtyas, D. (2019, November 19). Great Sale Simak Deretan Saham Konsumer Murah Meriah. https://www.cnbcindonesia.com/market/20191119125017-17-116278/great-sale-lagisimak-deretan-saham-konsumer-murah-meriah

Bambang, R. (2000). Dasar-dasar pembelanjaan perusahaan. Edisi Keempat, Cetakan Ketujuh, BPFE Yogyakarta, Yogyakarta, 59.

Brigham, E. F., \& Houston, J. F. (2010). Fundamentals of financial management. Cengage Learning.

Dewi, A. D. I. R., Artini, S., \& Gede, L. (2016). Pengaruh Suku Bunga SBI, Inflasi, Dan Fundamenal Perusahaan Terhadap Harga Saham Indeks Lq-45 Di Bei. E-Jurnal Manajemen Universitas Udayana, 5(4).

Eric, H. (2011). Analisis Laporan Keuangan. Jakarta: Erlangga.

Ghazali, I., \& Ratmono, D. (2016). Analisis Multivariat dan Ekonometrika Teori, Konsep dan Aplikasi dengan Eviews 8. Semarang: Universitas Diponegoro.

Habib, A. (2008). Kiat jitu peramalan saham. Jakarta: Gramedia Pustaka Utama.

Hartono, J. (2008). Teori portofolio dan analisis investasi. Yogyakarta: BPFE.

Horne, J. C. Van, \& Wachowicz, J. M. (2012). Prinsip-prinsip manajemen keuangan. Jakarta: Salemba Empat.

Kasmir, M. M. (2014). Analisis Laporan Keuangan, edisi pertama, cetakan pertama. Jakarta: Rajawali Pers.

Kemenperin. (2019). Industri Makanan dan Minuman Jadi Sektor Kampiun. kemenperin.go.id/artikel/. 
Industri-Makanan-dan-Minuman-Jadi-Sektor-Kampiun-.

Menon, D., \& Vidhyasagara, U. (2015). Impact of capital structure on stock prices: evidence from Oman. Impact of Capital Structure on Stock Prices: Evidence from Oman (September 25, 2015).

Ratih, D., Prihatini, A. E., \& Saryadi, S. (2014). Pengaruh EPS, PER, DER, ROE terhadap harga saham pada Perusahaan Sektor Pertambangan yang terdaftar di Bursa Efek Indonesia (BEI) tahun 2010-2012. Jurnal Ilmu Administrasi Bisnis, 3(1), 83-94.

Sakti, I. (2018). Analisis Regresi Data Panel Menggunakan Eviews. Modul Eviews, 9, 1-25.

Sudana, I. M. (2011). Manajemen keuangan perusahaan teori dan praktik. Jakarta: Erlangga.

Sugiyono, P. D. (2017). Metode Penelitian Bisnis: Pendekatan Kuantitatif, Kualitatif, Kombinasi, dan R\&D. Penerbit CV. Alfabeta: Bandung.

Sunariyah. (2011). Pengantar pengetahuan pasar modal. UPP Akademi Manajemen Perusahaan YKPN. Tryfino. (2009). Cara Cerdas Berinvestasi Sabam.

Widioatmodjo, S. (2013). Pengetabuan Pasar Modal untuk Konteks Indonesia. Elex Media Komputindo.

Winarto, J. (1997). Pasar modal Indonesia: retrospeksi lima tahun swastanisasi BEJ. Pustaka Sinar Harapan. 